\title{
CONSUMER VALUE CO-CREATION IN ONLINE BUSINESS: THE CASE OF GLOBAL TRAVEL SERVICES
}

\author{
Rasa SMALIUKIENE ${ }^{1}$, Lai CHI-SHIUN ${ }^{2}$, Indre SIZOVAITE ${ }^{3}$ \\ 1,3Vilnius Gediminas Technical University, Sauletekio al. 11, LT-10223 Vilnius, Lithuania \\ ${ }^{2}$ National Yunlin University of Science and Technology, 123 University Road, \\ Section 3, Douliou, Yunlin 64002, Taiwan, R.O.C. \\ E-mails: ${ }^{1}$ rasa.smaliukiene@vgtu.lt (corresponding author); \\ 2laics@yuntech.edu.tw; ${ }^{3}$ indre.sizovaite@vgtu.lt \\ Received 29 April 2014; accepted 04 November 2014
}

\begin{abstract}
This paper aims to examine the application of value co-creation approach in online travel service based on service-dominant logic. Drawing on recent works, the research indicates travellers as co-creators of value and emphasizes the development of customersupplier interaction. The paper presents three case studies to analyse global travel service suppliers' (service providers) behaviour: CouchSurfing International, Inc.; TripAdvisor LLC, AirBnbINc. Case studies analysis is followed by netnographic research of 22 different discussions (1243 records) in online forums related to selected service suppliers. The research findings suggest that value co-creation approach can be effectively used to analyse processes in global online travel service section. The originality of the paper lies in exploring the contribution of co-creation approach which allowed to identify the patterns of actions and behaviour of the online travel service providers and their consumers. As an additional value of the research, it was found that the online travel service providers integrate customer-to-customer interactions as a value co-creation in their platforms using consumers' resources such as time, knowledge and experience.
\end{abstract}

Keywords: value co-creation, service-dominant logic, travel services, online business, customer-to-customer interaction, case study, netnography.

JEL Classification: M3, D7, D8.

\section{Introduction}

Over the last century the consumer behaviour has fundamentally changed from isolated to connected, from unaware to informed, from passive to active, and almost all products and services must have a crucial digital component (Ramaswamy 2009). Rapid technological development and widespread Internet network has empowered customers by letting them share information, opinions and experiences as fast as never before. Changing technological environment and consumer behaviour became a threat for the old business models while co-creation came as the cornerstone for the marketing solutions and consumer value co-creation paradigm became a top research priority in marketing. 
Value co-creation in travel service is a wide spread phenomenon: a tourist empowered by the Internet and technologies has become knowledgeable and seeking exceptional value for money and time. According to the research (Rheem 2012), over 50\% of travellers from different countries are using general search engines for their destination selection and enjoy discussing travelling experiences with others. This indicates new sub-cultures of travellers: previously passive consumers and web surfers are now generating content, collaborating, commentating and online experience has shifted from searching and consuming to creating, connecting and exchanging (Paris et al. 2014). In accordance with the evolving service-dominant logic, the business model of travel agencies is shifting from trip-centric, when the trip as a complete package is sold to the customer, to the traveller-centric, when the trips are co-created with customers. Travellers' value perception rely no more on unilateral-firm approach, as structural changes in consumption are going on (Dudzevičiūte et al. 2014).

The phenomenon of value co-creation in travel service has been attracting researchers' attention. Previous research on value co-creation has focused mainly on offline interactions and encounters between a company and a traveller (Payne et al. 2009). Recently the situation has changed and dialogues in virtual networks are analysed (Ramaswamy 2009; Hoyer et al. 2010). The main focus is beyond provider-to-customer relations and traveller-to-traveller interactions outside the provider's sphere of influence (Grönroos, Voima 2013). Despite the considerable progress in tourism marketing research, the value co-creation has taken a too narrow perspective. This research seeks to expand the scope of study by including customer-to-customer interactions in value co-creation model and shifting from application to offline-to-online travel services.

Drawing on recent works, this research is based on service-dominant logic (S-D Logic) (Vargo, Lusch 2008; Grönroos 2012; Grönroos, Voima 2013). The central premise to S-D Logic indicates the proposition that the traveller becomes a co-creator of value and emphasizes the development of customer-supplier relationships through maintaining interaction and matching resources. It is the issue that this article seeks to address. Specifically, it reports on models which sought to describe the types and processes of consumer value co-creation as a positive outcome of consumer-supplier online interaction. The empirical part is devoted to mapping of three interconnected value-creating processes: consumer, supplier and encounter. Adopting conceptual typology of forms of customer co-creation, article analyses consumer's contribution level. To test this construct, we examine the travel companies' value co-creation using three case studies and netnography research of travellers.

\section{Theoretical framework}

\subsection{Value co-creation as a central concept of service-dominant logic}

Over the last century both large and small businesses have gradually shifted their marketing emphasis from production to sales and, recently, to consumers and their involvement into product creation (Longenecker et al. 2006; Pride, Ferrell 2006; Saarijärvi et al. 2013). Market structure and society have experienced major transformations since 
the beginning of the twenty-first century. In terms of marketing, this transformation encompasses marketing orientation changes from goods-dominant logic (G-D Logic) to service-dominant logic (S-D Logic) (Vargo, Lusch 2008).

The S-D logic was developed after it was recognized that more value can be created through services and engagement, experiences and communication with customers, rather than only providing a product. The S-D Logic is described by ten main foundational premises and their changes over time.

The first premise suggesting service as the fundamental basis of exchange is one of the premises that has reached consensus in theory of S-D Logic. Proposition that the customer is a co-creator (Vargo, Lusch 2008) or even a creator (Grönroos 2012) of value has always been as a central premise to service-dominant logic, which strongly emphasizes the development of customer-supplier relationships through marketing activities, interactions, dialogue (Payne et al. 2009; Prahalad, Ramaswamy 2013) and resource matching (Gummesson, Mele 2010; Aarikka-Stenroos, Jaakkola 2012).

In G-D Logic, value is perceived as value-in-exchange, usually as the endpoint of value chain where the goods are exchanged into money by the action of the purchase, like in a conventional consumer-product company, value is a function of products (Ramaswamy 2009) that are typically seen as the endpoint of the value chain. In contrast, in S-D Logic, value extends value chain and value is perceived as value-in-use and value-incontext (Grönroos, Voima 2013) where the whole period of product or service usage is also included as well as the impact of circumstances and context. In this case, the creator of value is not only the company, as it is in G-D Logic, but also customers and network partners.

Customers' active involvement ensures quality and goal achievement which is in line with agency theory customers (principal) monitor service agent fulfilment of the contract (Chan et al. 2010). At the same time an application of classical theories is not entirely correct as the relationship between customers and companies is not a contractual one (Lundkvist, Yakhlef 2004). The role of the company expands from producing and distributing value to proposing, co-creating value and providing service. Additionally, company creates a social context and determines its boundaries. In this way company's mission is not only to foster customers' engagement, but also to prevent their misbehaviour (Echeverri et al. 2012) or value co-destruction (Ple, Caceres 2010) that could result in a decline in at least of one of parties' well-being. S-D logic posits value co-creation as a social construct that represents how consumers perceive the norms of social reality, including their behaviour. Therefor not only consumer's contribution level but also evidence on citizenship needs to be included into research on value co-creation. At the same time value co-creation is perceived as joint activities by parties involved in direct interactions, aiming at contributing to the value that emerges for one or both parties and as a function of experiences other than the product itself, such as web platforms and environments for consumer interactions with the product and with a community of other users. 


\subsection{Top of Form Models of consumer value co-creation}

The type of consumer value co-creation depends on the interaction level between the customer and the company. Customer co-creation involves two key processes: contribution (submitting content) and selection (choosing one of these submissions will be retained). Using these two processes as foundation, Rindfleisch (2010) offers a conceptual typology of four different forms of customer co-creation that are: collaboration, tinkering, co-designing and submitting. All those forms could be measured using different methods for phenomenon evaluation (Ginevičius, Podvezko 2011). The lowest level of co-creation is submitting, i.e. fixed contribution and firm-led selection, and the highest level of co-creation is collaborating, i.e. open contribution and customer-led selection. Coates (2009) and Piller et al. (2010) provide more specific co-creation forms: mass collaboration, user-generated content, co-production, personalisation, mass customisation and mass production. All those given co-creation forms and types can be easily classified and illustrated (Fig. 1).

Collaboration is defined as a process in which customers have the power to collectively develop and improve a new product's core components and underlying structure. Collaboration approach is highly applicable in developing emerging ideas of consumers' goods (Hardyman et al. 2014). As it was discussed and shown in Fig. 1, collaboration is conceptualized as the form of co-creation that offers customers the greatest power to contribute their own ideas and to select the components that should be incorporated into a new product offering (Rindfleisch 2010; Aggarwal et al. 2014), it is also known as communities of creation for idea generation (Piller et al. 2010). However, collaboration can occur not only for the new product development or offering, but also for service (Grönroos, Voima 2013) or even experience creation (Prahalad, Ramaswamy 2013).

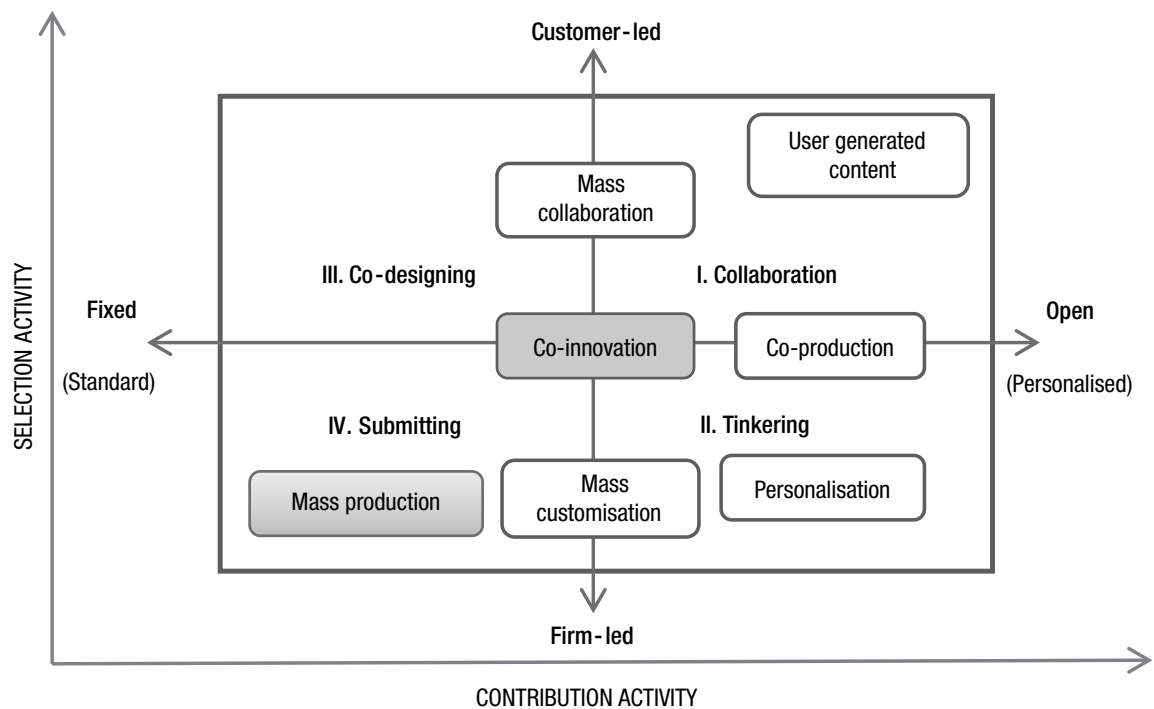

Fig. 1. Types of consumer value co-creation Source: adapted from Rindfleisch (2010) and Coates (2009). 
Coates (2009) accordingly provides user-generated content as a type of co-creation. User-generated content here is defined as content that is made publicly available through technologies such as the Internet, reflecting a certain amount of creative input or effort that is created outside of professional practices or routines. The highest level of contribution and selection is co-production - customer is an active participant in the production and delivery of service, giving the participant a potential to customize his or her world (Coates 2009). Other types of consumer value co-creation are less involving consumer, as the goal is to produce an affordable standardized product (Korsakienè, Baranauskienè 2011).

Collaboration in consumer value co-creation requires systemic approach. For that reason, co-creation management has to start with the building blocks of interactions between the company and the consumers that facilitate co-creation experiences. Prahalad and Ramaswamy (2013) offer the DART model as for managing co-creation of value processes and linking to consumer experiences. The DART model is a popular model in the co-creation process that can ensure that value co-creation is embedded in the early stage of development of a system. The main building blocks of the DART model suggested for value co-creation and co-creation experience generation are made up of four components (Prahalad, Ramaswamy 2013): D-dialogue, A-access, R-risk assessment and T-transparency.

Dialogue is defined as interactivity, engagement and propensity to act on both sides. Dialogue implies shared learning and communication between companies and consumers as two equal problem solvers. Dialogue helps to create and maintain loyal community (Prahalad, Ramaswamy 2013); it is a centre issue of interest to both and rules of engagement must be clearly defined in both sides.

Access describes how collaboration empowers customer access to information, knowledge and tools, by allowing value co-creation to follow (Spena et al. 2012).

Transparency fosters to create new levels of openness for information about products, technologies and business systems (Prahalad, Ramaswamy 2013).

Risk assessment refers to the probability of harm to the consumer. Active co-creators of value with companies will demand more information about potential risks of goods and services and they also may bear more responsibility (Prahalad, Ramaswamy 2013; Reay, Seddighi 2012).

The DART model is designed for managing value co-creation and linking business to consumer experiences. However, this model needs an extension as value co-creation occurs in interaction between a provider's sphere (provider's processes) and a customer's sphere (customer's processes). Process-based co-creation model proposed by Payne et al. (2009) involves customer's value creating processes, supplier's value creating processes and encounters that indicate interaction between the first two. Customer's process is described as a series of activities performed by the customer to achieve a particular goal. Supplier's process of creating value for the customer begins with an understanding of the customer's value-creating processes which links to opportunities for co-creation (Payne et al. 2008). Encounters indicate interactions between a customer's sphere and 
a supplier's sphere where supplier participates in customer value-in-use (Vargo, Lusch 2008; Grönroos, Voima 2013).

The process-based co-creation model illustrates interconnected activities between a supplier and a customer and locus of value co-creation process. This process based approach extends the DART model and leads towards the more sophisticated approach that is used for this research.

\section{Research methodology}

This paper provides the findings of two phases of qualitative research carried out to investigate collaborative process of value co-creation. Qualitative research was chosen as a relevant instrument for this study to gather information, as value co-creation in online service is a phenomenon that has not been sufficiently analysed and needs in deep qualitative analysis. An online travel service was chosen as the research context, as value co-creation in travel service is a wide spread phenomenon: many consumers have a reasonably high involvement with this service and it is expanding towards virtual communities.

Qualitative research of value co-creation in online travel service was conducted using two methods:

A. Case study of online travel service providers;

B. Netnography of online travel communities.

A. The purpose of the first phase of research was to identify how global travel service companies develop customer-supplier relationships through maintaining interaction and matching resources. Four main elements of the DART model - dialogue, access, risk and benefits, transparency -were analysed to answer the research question. The case study was selected as a beneficial research method for observing the processes and actions in online travel. Case study provided answers to question "how" (Yin 2009) that is essential for our research.

Three online travel service platform providers were selected according to the high number of registered users (more than one million) and period spent online cultivating provided travel service (more than 3 years). Three different companies (Table 1) were chosen which represent three different types: non-profit, public and private, which have emphasised importance also on different interactions and relationships with travel service users (customers). Each of the selected companies has provider-to-customer relationship by providing platform for interactions as well as a co-creation relationship; however, value co-creation can be focused on different areas.

Non-profit corporation (CouchSurfing) provides hospitality service platform were main focus is located on customer-to-customer interactions and value co-creation. Public corporation (TripAdvisor) providing travel services and having a huge network of suppliers concentrates on provider-to-customer value co-creation, and private company (AirBnB) has mixed type of interactions illustrated in both previous ones, here concentration is located on both supplier-to-customer and customer-to-customer value co-creation. 
Table 1. Companies providing value co-creation in online travel services

\begin{tabular}{clcccl}
\hline No. & Company name & Registered users & Founded in & Type & \multicolumn{1}{c}{ Industry } \\
\hline 1 & $\begin{array}{l}\text { CouchSurfing } \\
\text { International, Inc. }\end{array}$ & 5.5 million & 2004 & $\begin{array}{l}\text { Non-profit/ } \\
\text { B corp. }\end{array}$ & $\begin{array}{l}\text { Hospitality service, } \\
\text { social networking } \\
\text { services }\end{array}$ \\
\hline 2 & TripAdvisor LLC & 36 million & 2000 & Public & Travel services \\
\hline 3 & AirBnb, Inc. & 1 million & 2008 & Private & $\begin{array}{l}\text { Social networking } \\
\text { service }\end{array}$ \\
\hline
\end{tabular}

B. The second phase of the research examined interactions in online travel communities using netnography. Netnography can be defined as a specialized form of ethnographic research that has been adapted to the unique contingencies of various types of computermediated social interactions (Kozinets 2012). This research method was chosen due to specifications of analysed service which is online and answers required for examination and replenishment of value co-creation in online services can be absorbed by gathering data from communities such as social networking sites.

Netnography analysis was applied for online-communication amongst community members and customers of three selected online travel service providers - TripAdvisor, CouchSurfing and Airbnb-in order to find out mapping of customer, provider and encounter processes, referring to process-based co-creation model and previous research on European travel companies (Payne et al. 2008). Based on the assumption that general stages of the traveller and travel service provider remain the same online and offline, the model suggested by Payne et al. (2009) was used to examine value co-creation in online travel services.

Qualitative research was conducted by using 22 different discussions (1243 records) in online forums related to the selected cases of online travel service providers (Table 2). By using QSR NVivo 10 software for netnographic research, forums were coded and data was classified into customer-to-customer interactions and provider-to-customer interactions on online travel service.

Table 2.Selected online forums and discussions for netnographic research

\begin{tabular}{lll}
\hline No. & \multicolumn{1}{c}{ Topic of discussion } & Number of records \\
\hline 1 & TripAdvisor Forums// "Trip planning” & 198 \\
\hline 2 & TripAdvisor Forums// "On journey" & 120 \\
\hline 3 & TripAdvisor Forums// "preparation for ...trip" & 66 \\
\hline 4 & TripAdvisor Forums// "after trip" & 91 \\
\hline 5 & TripAdvisor Forums// "decision making” & 75 \\
\hline 6 & CouchSurfing Groups// "trip, trip plan, planning” & 82 \\
\hline 7 & CouchSurfing Groups// "host" & 141 \\
\hline
\end{tabular}


End of Table 2

\begin{tabular}{cll}
\hline No. & \multicolumn{1}{c}{ Topic of discussion } & Number of records \\
\hline 8 & CouchSurfing Groups// "guest" & 145 \\
\hline 9 & CouchSurfing Groups// "reference" & 102 \\
\hline 10 & AirBnb Official Blog & \\
\hline 11 & Tips on using Airbnb for monthly travel rentals & 29 \\
\hline 12 & Great experience with Airbnb in Paris & 4 \\
\hline 13 & Airbnb - Anyone used this site & 35 \\
\hline 14 & Being an Airbnb host & 13 \\
\hline 15 & Who has used AirBnb for accommodation before & 47 \\
\hline 16 & How best to use Airbnb as a host & 11 \\
\hline 17 & Experiences with Couchsurfing & 8 \\
\hline 18 & Couchsurfing tips & 8 \\
\hline 19 & Advanced CouchSurfing Tips & 27 \\
\hline 20 & CouchSurfing in Africa & 5 \\
\hline 21 & Are you familiar with Couchsurfing.com & 30 \\
\hline 22 & CouchSurfing & 6 \\
\hline & In total: & 1243 \\
\hline
\end{tabular}

\section{Value co-creation in online travel service platforms: the results of case study}

Cases analysis shows that all of selected online travel service companies in its processes has four main elements of the DART model and indicates that provided platforms can be used as an open area for consumer value co-creation. Dialogue in all three cases is started with access to information by providing a platform, i.e. an open area, where resources of both a provider and a customer can be integrated and matched. Tools and activities for dialogue, access, and transparency lead platform users, customers to an assessment of the risk-benefits and also to personalized action or decision making (Table 3).

Based on theoretical model, suppliers sphere and encounters were analysed. All three cases indicate suppliers' participation in customers' value-in-use: it is especially embodied in dialog activities and tools (see providers' activities in Table 3). However, there are also indirect interactions occurring in a provider's sphere, where the provider facilitates value and generates potential value-in-use, e.g. TripAdvisor's activities "Friend of a Friend" or "Destination experts" allows users to see reviews from second-degree contacts, making the user experience even more personalized. Identification of different interactions occurring among different subjects in all three cases determines encounters that could be classified and illustrated (Fig. 2). 
Table 3. Results of cases study: DART model application in of online travel service providers

\begin{tabular}{|c|c|c|c|c|}
\hline DART & Case & CouchSurfing & TripAdvisor & Airbnb \\
\hline \multirow[t]{5}{*}{ Dialog } & Customer & \multicolumn{3}{|c|}{$\begin{array}{l}\text { Participation behaviour: } \\
\text { Information seeking, information sharing, responsible behaviour, personal } \\
\text { interaction }\end{array}$} \\
\hline & & \multicolumn{3}{|l|}{ Citizenship behaviour: } \\
\hline & & $\begin{array}{l}\text { Feedback, advocacy, } \\
\text { helping }\end{array}$ & Advocacy & Helping, advocacy \\
\hline & Provider & \multicolumn{3}{|c|}{ Provides interactive space and tools to make: } \\
\hline & & $\begin{array}{l}\text { Profile, organized } \\
\text { events and activities, } \\
\text { thematic forums, } \\
\text { interactive map, } \\
\text { friend list, } \\
\text { volunteering } \\
\text { comments, } \\
\text { references }\end{array}$ & $\begin{array}{l}\text { Profile, friends of friend } \\
\text { reviews, destination } \\
\text { experts reviews, contacts } \\
\text { of hotels, restaurants, } \\
\text { flights, thematic forums, } \\
\text { interactive map, friend } \\
\text { of friend list, comments, } \\
\text { references }\end{array}$ & $\begin{array}{l}\text { Profile, detailed } \\
\text { selections for } \\
\text { accommodation, } \\
\text { thematic grouping of } \\
\text { resources, interactive } \\
\text { map, friend } \\
\text { list, comments, } \\
\text { references }\end{array}$ \\
\hline \multirow{2}{*}{\multicolumn{2}{|c|}{$\begin{array}{l}\text { Access } \\
\text { Web } \\
\text { platform }\end{array}$}} & \multicolumn{3}{|c|}{$\begin{array}{l}\text { Joint sphere for value cocreation of customer and provider where } \\
\text { resources of both are integrated: }\end{array}$} \\
\hline & & $\begin{array}{l}\text { Web platform } \\
\text { and smartphone } \\
\text { application (online } \\
\text { and offline) }\end{array}$ & \multicolumn{2}{|l|}{ Web platform } \\
\hline \multicolumn{2}{|c|}{ Trans-parency } & \multicolumn{3}{|c|}{$\begin{array}{l}\text { Customer has access to resources on platform and has freedom to express } \\
\text { positive or negative feedback visible in public }\end{array}$} \\
\hline \multirow{2}{*}{\multicolumn{2}{|c|}{$\begin{array}{l}\text { Risk and } \\
\text { benefits } \\
\text { References, } \\
\text { categories } \\
\text { of members, } \\
\text { profile } \\
\text { (verification, } \\
\text { vouching) }\end{array}$}} & \multicolumn{3}{|c|}{ Customer assesses risk and benefits depending on: } \\
\hline & & $\begin{array}{l}\text { Ranking, comments } \\
\text { photos, videos, } \\
\text { location }\end{array}$ & \multicolumn{2}{|l|}{$\begin{array}{l}\text { Reviews, profile, photos } \\
\text { location }\end{array}$} \\
\hline
\end{tabular}

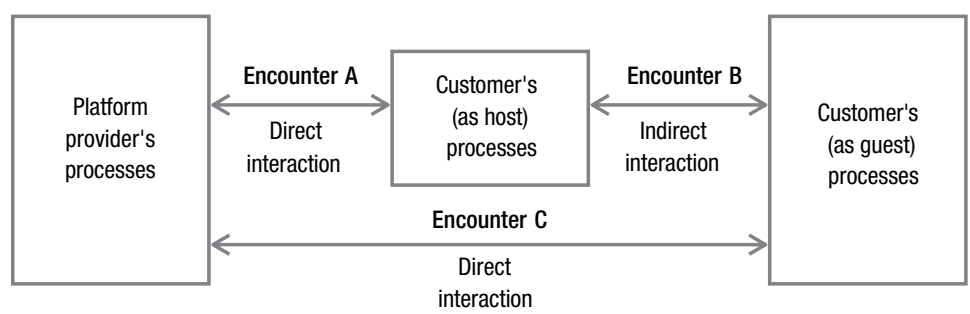

Fig. 2. Direct and indirect value co-creation interactions from the perspective of a provider (based on case study) 
All three cases show that most interactions occur within provider-to-customer relationships (Encounters A, Encounters C); however, there are examples (cases of CouchSurfing and Airbnb) of interactions that are also focused on customer-to-customer value co-creation (Encounter B). The case study shows that selected online travel providers meet basic requirements of the DART model that are obligatory for implementing value co-creation process.

\section{Customer value co-creation process: the results of netnographic research}

From the perspective of the platform provider, both guests and hosts are seen as customers. Netnographical research shows two types of behaviour: (1) customer-to-customer (host-to-guest) interaction on the platform which includes information seeking, customer know-how exchange in trip planning, experience sharing after the trip, and (2) customer/traveller citizenship related to feedback, advocacy, helping and tolerance. Information seeking. Members start their trip planning by trying to find like-minded people in their desired travel destination. Information seeking at this stage requires integrating traveller's resources such as a certain amount of personal information in profile (interests, pictures, personal description, etc.).

[Forum 16] - "A few people have recommended it, and I'm researching it/creating a profile/checking places etc. $<\ldots>$ Seems to be a lot about contacting the host and actually striking up a rapport with them, getting mates/family to write you references before you're going to be accepted though".

Personal interaction ensures that both the guest and the host are suitable for further co-creation of travel experience.

[Forum 15] - "if someone looks possible, ask them a few questions (a host once asked me for a little more information about me and my trip, which seemed reasonable)".

[Forum 12] - "read feedback carefully; only consider places with photos; look at exactly where the place is (maps are provided for each listing); establish a dialogue with the owner before committing".

Customer know-how exchange in trip planning. When both the guest and the host decide that their interests and goals in life match at their available period of time, then the customer's know-how exchange in trip planning takes place.

[Forum 16] - "Great reviews, well priced and communication has been great, she sent me an email before with a 4 page word doc with places to go, how to get from the airports to her place etc.".

Designing solutions on the trip illustrates customer-to-customer communication and value co-creation when the guest meets the host. The host and the guest contribute to value co-creation through the joint problem solving, planning joint activities, exchanging knowledge and culture.

[Forum 14] - "Some are delighted to be invited out with us, and really rate that as part of the AirBnB experience. We have a list of great local restaurants, cafes, bars etc in a 
file in the guest room. We take them to a cafe or bar sometimes, especially if they are single travelers looking to have a 'local' experience".

Experience sharing after the trip is related to different motives which are strongly interrelated in order to complete value co-creation as a continuous process bringing to the platform development and growth. Experiences, which can be good or bad, are usually shared independently from the provider by its customers.

[Forum 16] - "Highly recommend giving Airbnb a go, I will always check on there first if I am travelling somewhere in future".

Citizenship reflects interaction based on goals in life of both guest and host, such as feedback, advocacy, helping, tolerance and even sensitivity.

[Forum 14] - "When we get the sense that our guests want a more private time, we make ourselves scarce - we have our own time in our bedroom upstairs that leaves them free to use the rest of the space freely, or we go out".

By connecting guest-to-host value co-creation stages above, customer-to-customer value co-creation process can be illustrated as a closed and continuous process, beginning with information seeking and ending with experience sharing which will be used in the other member's information seeking stage. Value co-creation is in its highest level, as two subjects integrate their resources (time, knowledge, etc.) and get unique and very personal experience.

\section{Conclusions}

\section{Theoretical contribution}

The study showed that as opposed to offline travel service providers, online travel service providers are able to integrate customer-to-customer (guest-to-host) interactions and value co-creation into their platforms. Integrated customer-to-customer value cocreation process in the platform is one of the main driven factors for development and growth of the platform provider.

Comparing mapping of customer, provider and encounter processes in offline and online travel services, it can be concluded that value co-creation process is more active and intensive as customer and provider encounter more processes and the customer using his/her own resources (such as time, knowledge, experience, preferences, etc.) can co-create higher value in dialogue and interaction with the service provider. Study of online travel services showed particular importance on increasing effectiveness of the co-creation by integrating customer-to-customer interactions on the online platform and achieving an appropriate division of activities. The customer's active participation in value co-creating processes can reduce the platform provider's resource investments. The provider needs to take the manager role of value co-creation processes and organization of increasing amounts of resources.

Value co-creation can be established if the provider finds the way how to engage with its customers in their value-in-use processes. Integration of customer-to-customer com- 
munication is one of the ways to enhance the level of value co-creation on the platform as long as value co-creation process appearing in customer-to-customer interactions is independent from the provider.

\section{Managerial implication}

Integrated value co-creation process between guests and host brings relevant resources to the platform (such as reviews, experience sharing, references, etc.) and makes it a continuously growing process because information added by the last user will be used by the next user who then will have access to more information and resources.

Direct and indirect value of interactions was observed in each of the online travel service provider cases. Direct value co-creation process occurs when resources are integrated from the provider's and customer's sphere in one open area. The provider by giving access to the platform and appropriate tools for the customer can initiate and stimulate value co-creation. S-D Logic premises that the customer is always a value creator and co-creator. Therefore, value co-creation process consists of following stages: (1) Diagnosing traveller's needs, (2) Designing and producing the solution, (3) Implementing solution on the platform, (4) Managing value conflicts, (5) Organizing process and resources. Those stages of value co-creation process are seen from the provider's perspective as the provider of the platform needs to take initiative on interacting with the customer and find a way to join customer's value creation process.

Indirect value co-creation process shows the limit of value co-creation control from the perspective of the provider. Regarding to the suggestion for theoretical framework and results of conducted research on online travel services, value co-creating process in customer-to-customer (guest-to-host) interactions was edited and replenished into following stages: (1) Information seeking, (2) Personal interaction, (3) Customer knowhow exchange on trip planning, (4) Designing solutions on the trip, (5) Experience sharing after the trip.

Findings of the research correspond with previous findings of value co-creation through network, where actor to actor interactions enables each of them to enter the value creating processes of other parties, support them, and benefit from them. However results of value co-creation in online travel services show more flexibility in value co-creation and resource integration as customer can access the platform on the go and depending on the context, as well as offline interactions can be integrated in online platforms and become as a resource for other customers.

\section{Future research suggestions}

The findings of study indicate to a wider range of questions about the future of consumer's behaviour in networked daily life, their travel experiences and willingness to co-create; therefore, a particular interest for the future research should be focused on the Digital Savvy consumers who travel on their own. The future research should continue to look at how resources should be cultivated and organized on online travel service platforms and find out the ways to segment and gather like-minded people that could get higher satisfaction of co-creation by using online service. 
The future research should also investigate the impact of different cultures and subcultures on consumer value co-creation process in order to achieve effectiveness of customer-to-customer interaction integration into the platform and increase customer satisfaction by providing comfortable tools to share experiences, opinions and reviews. Investigations on different experience sharing could be also conducted. Experiences could vary depending on the purpose of travelling, starting with ordinary holidays, food traveling and ending with religious and pilgrimage journeys.

Finally, in view of the controversy of conceptual definitions of value co-creation the different outcomes of consumers' interactions are essential for future research. Future research needs to provide evidence not only on positive but also on negative effects of value co-creation as co-destruction or consumer misbehaviour in online platforms.

\section{References}

Aarikka-Stenroos, L.; Jaakkola, E. 2012. Value co-creation in knowledge intensive business services: a dyadic perspective on the joint problem solving process, Industrial Marketing Management 41(1):15-26. http://dx.doi.org/10.1016/j.indmarman.2011.11.008

Aggarwal, S.; Gupta, A.; Govindan, K.; Jha, P. C.; Meidute, I. 2014. Effect of repeat purchase and dynamic market size on diffusion of an innovative technological consumer product in a segmented market, Technological and Economic Development of Economy 20(1): 97-115.

http://dx.doi.org/10.3846/20294913.2014.885914

Chan, K. W.; Yim, C. K.; Lam, S. S. 2010. Is customer participation in value creation a doubleedged sword? Evidence from professional financial services across cultures, Journal of Marketing 74(3): 48-64. http://dx.doi.org/10.1509/jmkg.74.3.48

Coates, N. 2009. Co-creation: new pathways to value: an overview [online], [cited 15 May 2014]. Available from Internet: http://personal.lse.ac.uk/samsona/CoCreation_Report.pdf

Dudzevičiūtè, G.; Mačiulis, A.; Tvaronavičienè, M. 2014. Structural changes of economies: Lithuania in the global context, Technological and Economic Development of Economy 20(2): $353-370 . i$

Echeverri, P.; Salomonson, N.; Aberg, A. 2012. Dealing with customer misbehaviour. Employees' tactics, practical judgement and implicit knowledge, Marketing Theory 12(4): 427-449.

Ginevičius, R.; Podvezko, V. 2011. A feasibility study of multicriteria methods' application to quantitative evaluation of social phenomena, Business: Theory and Practice 9(2): 81-87.

Grönroos, C.; Voima, P. 2013. Critical service logic: making sense of value creation and cocreation, Journal of the Academy of Marketing Science 41(2): 133-150.

http://dx.doi.org/10.1007/s11747-012-0308-3

Grönroos, C. 2012. Conceptualising value co-creation: a journey to the 1970 s and back to the future, Journal of Marketing Management 28(13-14): 1520-1534.

http://dx.doi.org/10.1080/0267257X.2012.737357

Gummesson, E.; Mele, C. 2010. Marketing as value co-creation through network interaction and resource integration, Journal of Business Market Management 4(4): 181-198.

http://dx.doi.org/10.1007/s12087-010-0044-2

Hardyman, W.; Daunt, K. L.; Kitchener, M. 2014. Value co-creation through patient engagement in health care: a micro-level approach and research agenda, Public Management Review (aheadof-print) 1-18. 
Hoyer, W. D.; Chandy, R.; Dorotic, M.; Krafft, M.; Singh, S. S. 2010. Consumer co-creation in new product development, Journal of Service Research 13(3): 283-296.

http://dx.doi.org/10.1177/1094670510375604

Korsakienè, R.; Baranauskienè, A. 2011. Factors impacting sustainable internationalization: a case of multinational company, Journal of Security and Sustainability Issues 1(1): 53-62.

http://dx.doi.org/10.9770/jssi.2011.1.1(5)

Kozinets, R. V. 2012. Marketing netnography: prom/ot(ulgat)ing a new research method, Methodological Innovations Online 7(1): 37-45.

Longenecker, J. G.; Moore, C. W.; Petty, J. W.; Palich, L. E. 2006. Small business management: an entrepreneurial emphasis. 13th ed. Thomson South-Western.

Lundkvist, A.; Yakhlef, A. 2004. Customer involvement in new service development: a conversational approach, Managing Service Quality 14(2/3): 249-257.

http://dx.doi.org/10.1108/09604520410528662

Paris, C. M.; Musa, G.; Thirumoorthi, T. 2014. A comparison between Asian and Australasia backpackers using cultural consensus analysis, Current Issues in Tourism (ahead-of-print) 1-21.

Payne, A. F.; Storbacka, K.; Frow, P. 2008. Managing the co-creation of value, Journal of the Academy of Marketing Science 36(1): 83-96: 1552-7824.

http://dx.doi.org/10.1007/s11747-007-0070-0

Payne, A. F.; Storbacka, K.; Frow, P.; Knox, S. 2009. Co-creating brands: diagnosing and designing the relationship experience, Journal of Business Research 62(3): 379-389.

http://dx.doi.org/10.1016/j.jbusres.2008.05.013

Piller, F. T.; Ihl, C.; Vossen, A. 2010. A Typology of Customer Co-Creation in the Innovation Process [online], [cited 30 November 2011]. Available from Internet: http://papers.ssrn.com/sol3/ papers.cfm?abstract_id=1732127. http://dx.doi.org/10.2139/ssrn.1732127

Ple, L.; Caceres, R. C. 2010. Not always co-creation: introducing interactional co-destruction of value in service-dominant logic, Journal of Services Marketing 24(6): 430-437.

http://dx.doi.org/10.1108/08876041011072546

Prahalad, C. K.; Ramaswamy, V. 2013. The future of competition: co-creating unique value with customers. Harvard: Harvard Business Press.

Pride, W. M.; Ferrell, O. C. 2006. Marketing - concepts and strategies. 13th ed. Houghton: Mifflin Company.

Ramaswamy, V. 2009. Leading the transformation to co-creation of value, Strategy \& Leadership 37(2): 32-37: 1087-8572. http://dx.doi.org/10.1108/10878570910941208

Reay, P.; Seddighi, H. R. 2012. An empirical evaluation of management and operational capabilities for innovation via co-creation, European Journal of Innovation Management 15(2): 259-275. http://dx.doi.org/10.1108/14601061211221002

Rheem, C. 2012. Empowering Inspiration: the Future of Travel Search [online], [cited $24 \mathrm{Au}-$ gust 2013]. PhocusWright - Global Travel Market research. Available from Internet: www. phocuswright.com/free_reports/empowering-inspiration-the-future-of-travel-search

Rindfleisch, A. 2010. Customer co-creation: a typology and research agenda, in N. K. Malhotra (Ed.). Review of marketing research. Emerald Business, Management and Economics eBook Series Collection.

Saarijärvi, H.; Kannan, P. K.; Kuusela, H. 2013. Value co-creation: theoretical approaches and practical implications, European Business Review 25(1): 6-19.

http://dx.doi.org/10.1108/09555341311287718

Spena, T. R.; Caridà, A.; Colurcio, M.; Melia, M. 2012. Store experience and co-creation: the case of temporary shop, International Journal of Retail \& Distribution Management 40(1): 2140. http://dx.doi.org/10.1108/09590551211193586 
Vargo, S. L.; Lusch, R. F. 2008. Service dominant logic: continuing the evolution, Journal of the Academy of Marketing Science 36(1): 1-10. http://dx.doi.org/10.1007/s11747-007-0069-6

Yin, R. K. 2009. Case study research: design and methods. 4th ed. SAGE Publications Ltd.

Rasa SMALIUKIENE holds a $\mathrm{PhD}$ in Business Administration and is Professor at International Economics and Management Department in Vilnius Gediminas Technical University. Her research focuses on marketing, consumer behavior and leadership.

Lai CHI-SHIUN, Professor and Chairman Department of Business Administration in National Yunlin University of Science and Technology. His research interests focus on channel relationships, buyerseller relationships and services marketing.

Indre SIZOVAITE holds Master in Marketing. Her research interests are in consumer behavior and e-business solutions. 